\title{
Pactos, conflictos y papeles: los museos y la prensa
}

Lourdes Carbonell Hidalgo*

Cuando José Martí, en un cuaderno de apuntes de 1881, expresaba: “Qué trabajo cuesta hallarse a sí mismo...", había denominado con ello el proceso que comporta la identidad en el individuo y había subrayado que ese proceso no era un camino fácil, al contrario, establecía que las búsquedas de la identidad se presentaban como fruto de una brega constante, donde los elementos históricos creaban el espacio y la autenticidad diseñaba las imágenes de lo que culturalmente distingue a los grupos humanos, quienes hacen un devenir social común en las diferentes regiones del planeta.

José Lezama Lima incorporaría a esta idea el significado que tiene el lenguaje en la misión de dar un cosmos a la identidad, y apuntaba: "Lo más valioso en el idioma es el destino afortunado de su uso", ${ }^{2}$ con lo cual estaba definiendo la importancia que en el caso americano tenia la evolución del lenguaje en el proceso de identidad, pues las obras literarias creadas por los primeros grandes escritores latinoamericanos constituían la visión de un universo diferente al de la metrópoli española, por tal motivo destacaba que la fortuna más trascendente en el lenguaje americano la habían aportado, entonces, Martí, Darío y Vallejo cuando: "Lanzan su acto naciente verbal rodeado de ineficacia y de palabras muertas...". La metáfora lezamiana explica un asunto por atender; y es que en todas las épocas ha habido hombres que, profundamente asistidos de su esencia social, hacen un acto comunicativo que desbroza los

* Lourdes Carbonell Hidalgo, licenciada en Ciencias Sociales en el Instituto Superior Pedagógico de
Santiago de Cuba. Directora del Centro de Patrimonio Cultural de Granma. Posee la Distinción por
la Cultura Cubana, la Medalla XXX Aniversario de la desaparición física de Ernesto Che Guevara
y la Orden Juan Marinello. Representante de Cuba en Ibermuseos, ha realizado investigaciones con
resultados publicados en la revista Cinco Palmas de la Oficina de Asuntos Históricos del Consejo de
Estado. Coautora del libro Fidel entre nosotros, testimonios de la presencia del líder de la Revolución
en Granma. 1 Martí. José Obras completas. La Habana: Editorial de Ciencias Sociales, 1975.

2 Lezama Lima, José. En busca de la expresión americana. La Habana: Editorial Letra Cubana, 1985. 


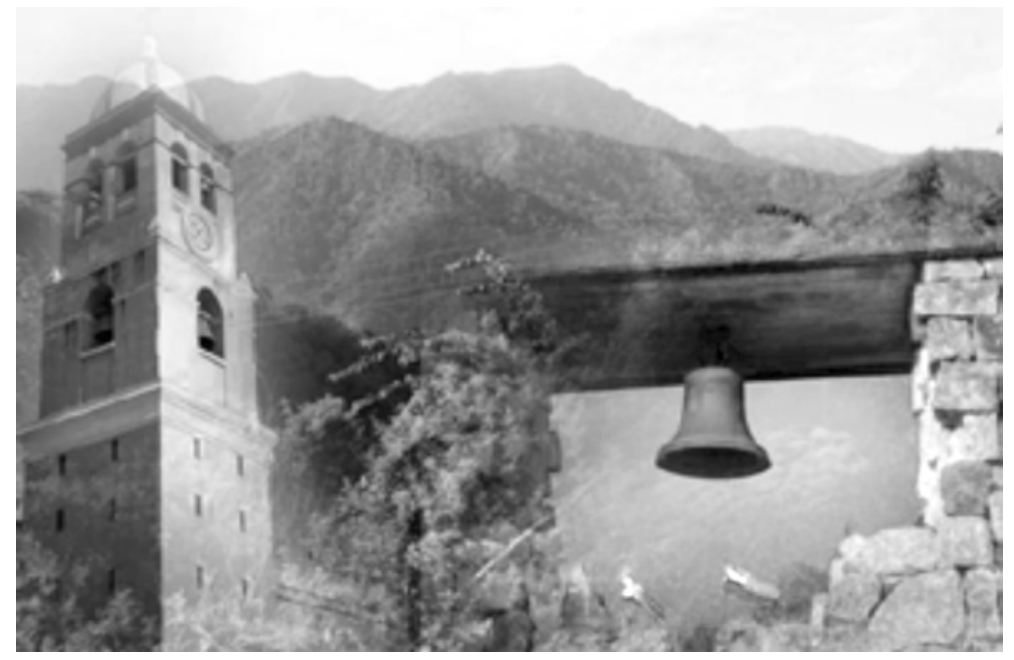

lenguajes estériles y la falta de asuntos de interés social que tengan valores culturales distintivos de las diferentes comunidades humanas y que constituyen su patrimonio.

Si comprendemos el apartado anterior, podemos ahora significar que las funciones de los museos y la prensa tienen una coherencia que constituye la misión de ambos: la construcción de un sistema de valores profundamente asimilados por la sociedad en defensa de la identidad.

Este proceso es metodológicamente organizado por las instituciones museísticas que regulan la preservación de las herencias sociales, que luego son promovidas por diferentes vías donde la eficacia muchas veces radica en el papel que asume la prensa como promotora de un diálogo en el que el individuo ve reflejadas sus maneras de ser y sus prácticas culturales.

Toca entonces a ambas entidades sociales indagar, asumir tareas, ser expresión de la sensibilidad y del imaginario colectivo, permitiendo que los mensajes éticos que animan los movimientos sociales lleguen con un subrayado que haga valedero el mensaje. En los tiempos que hoy vivimos las convocatorias a la mirada profunda hacia los museos corren siempre por cuenta de la unidad de los medios de difusión con nuestras instituciones, constituyendo para estos medios un reto la asimilación de una conducta indagadora hacia los asuntos históricos, los procesos culturales y las aspiraciones que nuestra sociedad plantea al futuro. En ello hemos sido beneficiarios permanentes en Cuba. 
Corresponde a los tiempos que corren asimilar la lección de los padres fundadores de la nación, quienes dejaron en la prensa los resultados de sus actos comunicativos -entiéndase discursos, artículos, polémicas, epistolarios, obras artísticas - de un modo tan abrumador que hoy constituyen las principales fuentes documentales de la investigación; por tal motivo, se abre ante nosotros un horizonte cargado de expresiones constantes del ejercicio reflexivo sobre el patrimonio y la cultura, que deben tener cada día mayor espacio en los medios de comunicación.

Para soslayar cualquier comprensión de que venimos a un lamento, queremos expresar que nuestra reflexión anterior trata de comunicar el quehacer contemporáneo de la prensa hacia el patrimonio, que ha vivido interesantes momentos de trabajo común con ejemplos tales que sería oportuno mencionar aquí. Son los casos de los sistemáticos artículos que permanentemente publica el periódico Granma, órgano oficial del Estado cubano, de conjunto con los museólogos, los trabajos de diversas facturas que durante los eventos de museos se realizan por la Agencia Nacional de Información, AIN, estableciendo nexos con emisoras de otras regiones, impactando con ello en el auditorio de esas regiones, los eficaces trabajos reporteriles de los telecentros locales y la TV nacional, a propósito de la conservación, restauración y proyectos que realizamos en defensa del patrimonio, o los oportunos trabajos informativos especializados que realizan los círculos de periodistas; y que constituyen un banco de imágenes de patrimonio y arte del que hacemos uso frecuentemente todos.

Un inteligente recorrido por el patrimonio intangible han realizado agencias informativas por el quehacer de las montañas de la isla, cargadas de testimonios y fabulaciones que explican su tradición de bastión revolucionario. Otro singular ejemplo de coherencia informativa con el patrimonio lo ha constituido la acción aguda y ágil del periodista David Rodríguez, que en su escuchado programa radial "Hoy en la Noticia" - que inicia el día en Granma - siempre diseña un espacio para la actualidad patrimonial y dedica las campanas de la Iglesia Mayor a los museos. Estos constituyen los momentos referentes de un paradigma en el que todos nos vemos reflejados y con el que estamos comprometidos.

Es válido para nosotros, y constituye una constante, convocar nuevas lecturas sobre zonas patrimoniales, sobre nuevas colecciones y otros museos de gran envergadura, y que se ofrecen como temas interesantes por laborar por los 
expertos de la prensa. Son los casos del patrimonio natural, que tiene su máxima expresión en el parque "Desembarco del Granma", patrimonio de la humanidad por sus valores naturales, el que además registra los caminos de la epopeya de la llegada de Fidel a Cuba en su expedición del 2 de diciembre de 1956; los inventarios del patrimonio inmaterial, expresión del imaginario popular, que hoy conforman catálogos en los museos; los monumentos declarados que signan acontecimientos de varias épocas. Para las creaciones periodísticas alrededor de estos temas, les decimos que hemos generado espacio de encuentros por celebrarse en cada mes, donde una comisión de trabajo estará dedicada exclusivamente a los alentadores vínculos de la prensa y los museos.

En estos momentos de futuro queremos parafrasear el pensamiento de Martha Arjona, que escribió: "La palabra patrimonio significa lo que se recibe de los padres y lo que es de uno por derecho propio... Pero hay también un significado mucho mas amplio de lo que es Patrimonio, que no tiene que ver
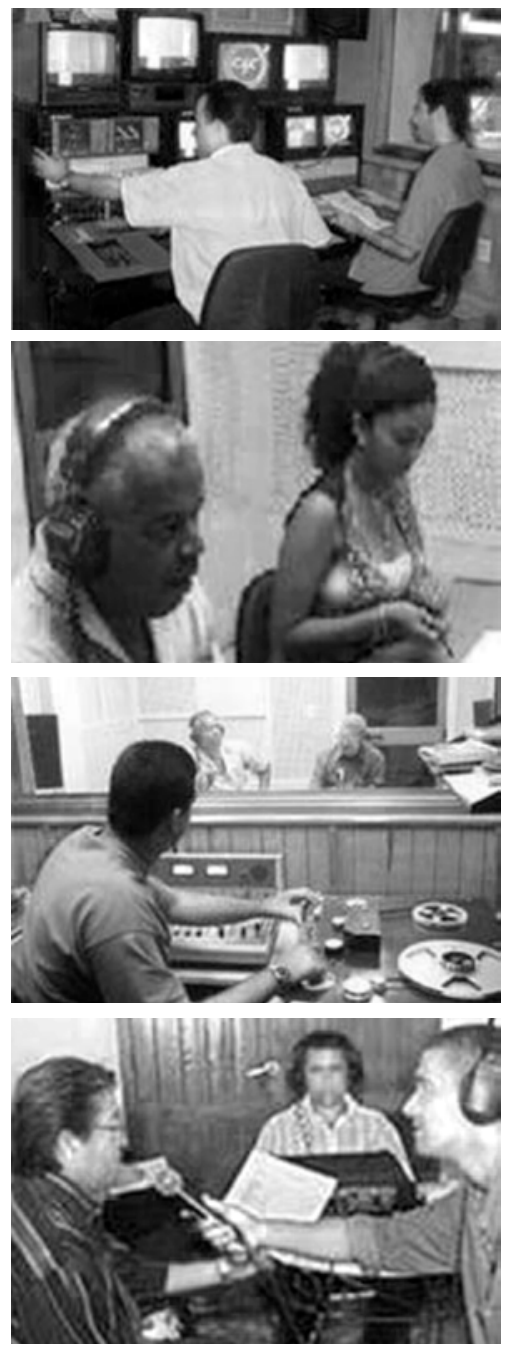

Programas de museos y prensa.

Bayamo, Monumento Nacional. con un individuo... sino que se refiere a los de una nación entera" ${ }^{1}$ El patrimonio, en este amplio sentido, constituye nuestra máxima riqueza y nos identifica entre otros pueblos. Trabajemos juntos por ampliar esta riqueza, y estaremos defendiendo la identidad de la nación cubana.

La participación en el intercambio mediático de las instituciones, promoviendo los efectos del patrimonio, validan el trabajo de protección en el ámbito de un público masivo.

1 Arjona Pérez, Martha. Patrimonio cultural e identidad. La Habana: Publicaciones de la Oficina del Historiador, Ediciones Boloña, 2003. 

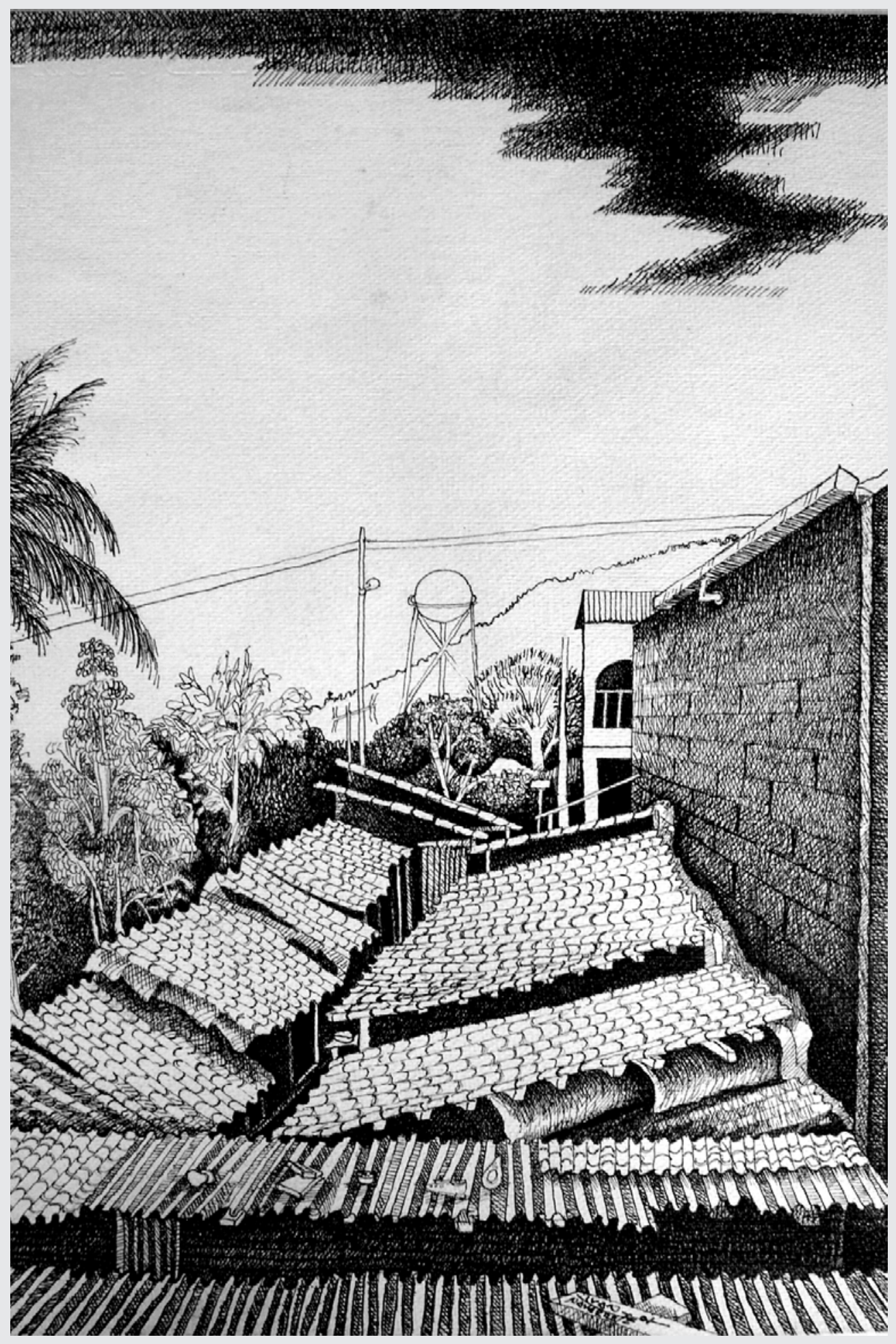